DOI: $10.36648 / 2471-8505.6 .2 .8$

\title{
White Lung with Milky Effusion
}

\section{Abstract}

Chylothorax is caused by disruption or obstruction of the thoracic duct or its tributaries that results in leakage of chyle, which can be of traumatic or nontraumatic in origin. Traumatic Chylothorax is reported as postoperative complication, mainly post thoracic surgery with few reported cases post spinal surgery especially left chylothorax post posterior approach.Ultrasound chest play an important bedside tool for rapid diagnosis of acute dyspnea, Drainage of massive effusion and daily follow up after drainage.

We present a 71- year-old female patient underwent spinal fixation surgery, developed progressive dyspnoea post operatively. Point-Of- Care-ultrasound confirmed the presence of massive pleural effusion. Ultrasound guided drainage revealed cloudy whitish fluid with high triglyceride level confirming chylothorax. The patient was managed conservatively and intravenous octreotide. Follow up Chest ultrasound revealed decreasing effusion and chest tube removed 5 days post insertion.

This is a rare complication of a common procedure. Ultrasound chest is essential tool for diagnosis of the cause of acute dyspnoea, treatment of some causes and follow up.

Keywords: Chylothorax, Acute dyspnea, Chyle, Thoracic surgery.

\section{Tamer Mohamed Zaalouk*, Zouheir llbrahim Bitar, Ossama Sajeh Maadarani, ALAsmar Mohammed El- shably}

Critical Care Unit, Ahamdi Hospital, Kuwait Oil Company, Fahaheel, Kuwait

\author{
*Corresponding author: \\ Tamer Mohamed Zaalouk \\ forevertn@hotmail.com \\ Critical Care Unit, Ahamdi Hospital, Kuwait Oil \\ Company, Fahaheel, Kuwait
}

Citation: Zaalouk TM, Bitar ZI, Maadarani OS, El-shably AM (2020) White Lung with Milky Effusion. J Intensive \& Crit Care Vol.6 No.2:8

\section{Case Presentation}

71-year-old-woman admitted with acute low back pain of 8 weeks duration that became severe three days before admission. Pain is limited to left lower costal margin with no midline or paravertebral pain. There was tenderness at thoracolumbar junction and over lower ribs and left paraspinal muscles. Reflexes and motor power were normal in four limbs. No cranial nerves affection.

MRI spine showed D8-9 spondylodiscitis with soft tissue collection. Patient underwent surgical debridement and fixation form D6-D7 to D10-D11 with fusion D8-9, through direct dorsal approach. Fixation of transpedicular screws diameter 6.5 length $35 \mathrm{~mm}$ in dorsal and $60 \mathrm{~mm}$ diameter, length $40 \mathrm{~mm}$ in lumbar, Medtronic decompression then debridement of D8-9-disc level bilaterally.

On day 3 postoperatively, patient had progressive dyspnea and CXR showed complete opacification of left lung. Urgent ultrasound chest showed massive left pleural effusion with Plankton sign. Chest tube, pigtail size 8 French was inserted at intercostal space and drained cloudy milky fluid. It drained 2.5 liters over 24 hours. Pleural fluid showed high triglyceride 800 $\mathrm{mg} / \mathrm{ml}=10.10 \mathrm{mmol} / \mathrm{L}$, with total protein was $(36.8 \mathrm{~g} / \mathrm{L})$, total cholesterol $180 \mathrm{md} / \mathrm{dl}(4.8 \mathrm{mmol} / \mathrm{L})$.

Chylothorax was confirmed and Patient was kept NPO, TPN and somatostatin infusion has started. Left pleural effusion was decreased in subsequent days.

Follow up CT chest showed - Multiple spinal fixation screws are noted in the D6 TO D10 vertebral bodies. Left D6 screw is seen extending via the pedicle into the mediastinum, just medial to the descending aorta and just touching the esophagus. Left D8 screw is not visualized. Both D9 and D10 screw on left side is seen penetrating the anterior vertebral cortex extending into the prevertebral soft tissue. Multiple bony fragment noted in the left half D8 vertebral body (Figures 1 and 2). 


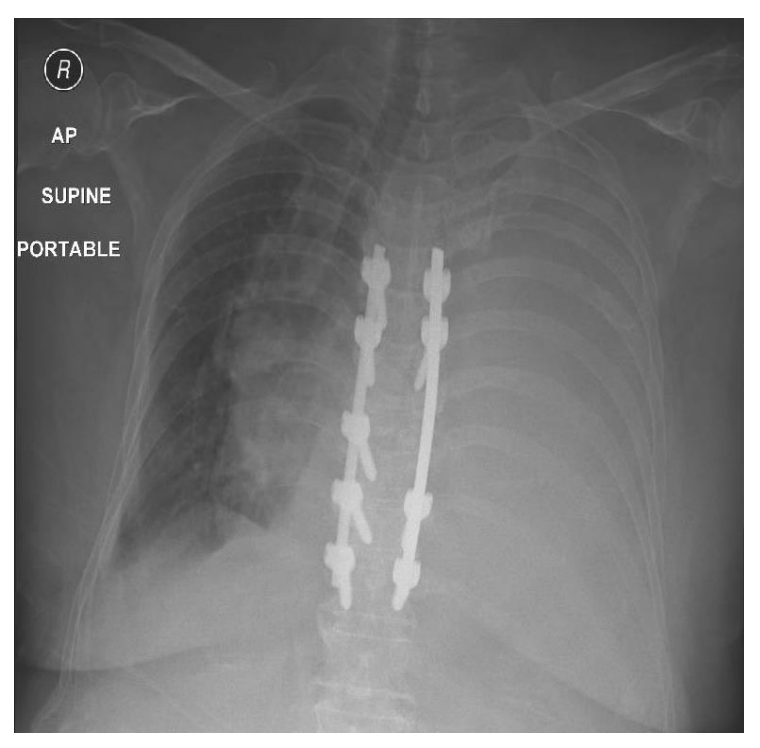

Figure 1 CXR with opacification of left lung and dorsal spine fixation.

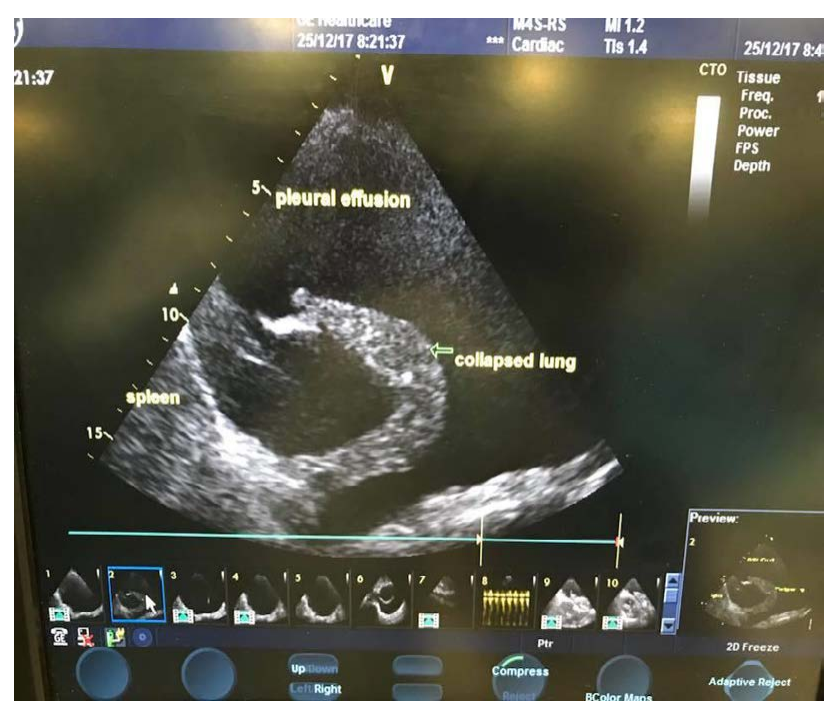

Figure 2 Ultrasound chest with left hemothorax.

This scan shows substantial effusion with multiple echoes, mobile and whirling in real-time (plankton sign). The lower lobe is consolidated.

\section{Results}

Body Fluid Total Protein- $36.8 \mathrm{~g} / \mathrm{L}$

Body Fluid Lactate Dehydrogenase- $154 \mathrm{U} / \mathrm{L}$

Body Fluid Adenosine Deaminase- $1.5 \mathrm{nmol} / \mathrm{min}$

Blood Gas pH- 7.42

Triglycerides Level- $10.10 \mathrm{mmol} / \mathrm{L}$

Body Fluid Total Protein- $36.8 \mathrm{~g} / \mathrm{L}$

Body Fluid Lactate Dehydrogenase- $154 \mathrm{U} / \mathrm{L}$

$\mathrm{CBC}$, renal pannle, liver enzymes, TFT were all normal
Chest tube was removed after 5 days with drainage less than 50 $\mathrm{ml} /$ day for 2 days. Follow up US chest showed minimal effusion. Patient was discharged home in a stable condition.

\section{Discussion}

Chyle is lymphatic fluid drained from the intestine to the blood stream through the thoracic duct. Chyle has a milky appearance that clears during fasting because of the high content of triglycerides in the form of chylomicrons, opalescent appearance of lymphatic fluid. It also has bacteriostatic activity as it contains lymphocytes (primarily $\mathrm{T}$ lymphocytes) as the major cellular component (>70 percent) [1]. The thoracic duct passes through the mediastinum, where receives nonchylous lymph from tributaries that drain regions of the pulmonary parenchyma and parietal pleura [2]. The total lymphatic flow through the thoracic duct of 1500 to $2400 \mathrm{~mL} /$ day [3].

Chylothorax can be traumatic or nontraumatic with equal incidence [4]. The etiology of chylothorax likely also varies by the patient population managed in the reporting institution. In traumatic chylothorax, disruption of the thoracic duct or its tributaries anywhere along their course can cause a chylothorax [5]. Surgical procedures, such as Esophagectomy [6], pulmonary resection with lymph node dissection [7], surgery for congenital heart disease (including heart-lung transplantation in the thoracic duct or nearby structures, which account for the majority of cases of traumatic chylothorax, can disrupt the thoracic duct or tear lymphatic tributaries $[8,9]$. Many reported cases in association with every complicated thoracic or abdominal procedure $[10,11]$.

The milky-appearing fluid suggests the presence of a chylothorax, but other differential diagnosis should be considered e.g cholesterol pleural effusion, or an empyema. The WBCs count is elevated but mainly lymphocytes of a polyclonal population of T cells, and this can rule out empyema. Pleural fluid triglyceride content measurement is the initial test to diagnosis a chylothorax. A pleural fluid triglyceride concentration greater than 110 $\mathrm{mg} / \mathrm{dL}$ (1.24 mmol/L) strongly supports the diagnosis [12]. Lipoprotein electrophoresis of pleural effusion is reserved for patients with an intermediate pleural fluid triglyceride level between $50 \mathrm{mg} / \mathrm{dL}$ and $110 \mathrm{mg} / \mathrm{dL}$ [13]. In our case the level was high, and we did not need to do electrophoresis. The cholesterol level in a chylothorax is generally less than 200 $\mathrm{mg} / \mathrm{dL}$ (5.18 mmol/L) [13].

Usually an injury to the thoracic duct at or below the fifth thoracic vertebra results in a right-sided chylothorax, and injury above the fifth thoracic vertebra would result in a left-sided chylothorax [14]. However, an anatomic variation of the normal course, which is not uncommon, could explain the left-sided chylothorax in our patient [15]. Bhat et al reported 3 cases of Chylous leakage is uncommon complication following anterior spinal surgery, it followed thoracic duct, cisterna chyli or retroperitoneal lymphatic vessel injury. AL cases were managed nonoperatively [16]. In Multicenter retrospective case series, 9591 patients reviewed that underwent cervical spine surgery, only 2 cases $(0.02 \%)$ had iatrogenic injury to the thoracic duct [17]. Both patients underwent a left-sided anterior cervical discectomy and fusion and managed conservatively. 
Depending on the volume of chyle loss, Chylothorax can be lowoutput chylothoraxes ( $<1000$ chyle drainage per day) or large volume drainage ( $>1 \mathrm{~L}$ per day) of chylous. Large leaks can cause nutritional deficiencies, respiratory dysfunction, dehydration and immunological dysfunction [18]. Conservative treatment is recommended initially for post-traumatic chylothorax. Conservative treatment is recommended initially for posttraumatic chylothorax. Standard methods include chest tube drainage, dietary restriction and total parenteral nutrition. If these prove ineffective, somatostatin can be given by continuous infusion. Patients draining more than 1 L/day are unlikely to respond to conservative therapy and usually require surgical intervention usually thoracic duct ligation within 5 to 7 days [19]. In our patient, the lymphatic drainage was less than $500 \mathrm{~mL}$ of chest tube drainage after initiation of medical treatment and did not require surgical intervention.

\section{Conclusion}

Thoracic duct injury is a rare complication of dorsal spine operations. Conservative treatment in postoperative chylous leakage is an option with measures to decrease chylous formation can lead to a complete resolution of chylothorax.

\section{Declarations}

Competing interests: The author(s) declared no potential conflicts of interest with respect to the research, authorship, and/or publication of this article.

Funding: The authors received no financial support for the research, authorship, and/or publication of this article. The research was performed as part of the employment of the authors in Kuwait oil Company.

Authors' contributions: Tamer Zaalouk wrote the article, Zouheir Ibrahim Bitar and Ossama S. Maadarani shared in the discussion and ALAsmar Mohammed El-shably in collecting the data and revision of the manuscript.

\section{References}

1. Doerr CH, Miller DL, Ryu JH (2001) Chylothorax. Semin Respir Crit Care Med 22: 617.

2. Weidner WA, Steiner RM (1971) Roentgenographic demonstration of intrapulmonary and pleural lymphatics during lymphangiography. Radiology 100: 533

3. Macfarlane JR, Holman CW (1972) Chylothorax. Am Rev Respir Dis 105: 287.
4. Doerr CH, Allen MS, Nichols FC, Ryu JH (2005) Etiology of chylothorax in 203 patients. Mayo Clin Proc 80: 867.

5. Karapolat S, Sanli A, Onen A (2008) Chylothorax due to tuberculosis lymphadenopathy: report of a case. Surg Today 38: 938.

6. Miao L, Zhang Y, Hu H, Ma L (2015) Incidence and management of chylothorax after esophagectomy. Thorac Cancer 6: 354-358.

7. Bryant AS, Minnich DJ, Wei B, Cerfolio RJ (2014) The incidence and management of postoperative chylothorax after pulmonary resection and thoracic mediastinal lymph node dissection. Ann Thorac Surg 98: 232.

8. Ferguson MK, Little AG, Skinner DB (1985) Current concepts in the management of postoperative chylothorax. Ann Thorac Surg 40: 542.

9. Terzi A, Furlan G, Magnanelli G, Terrini A, Ivic N (1994) Chylothorax after pleuro-pulmonary surgery: a rare but unavoidable complication. Thorac Cardiovasc Surg 42: 81-84.

10. Doerr CH, Allen MS, Nichols FC 3rd, Ryu JH (2005) Etiology of chylothorax in 203 patients. Mayo Clin Proc 80: 867.

11. Zabeck H, Muley T, Dienemann H, Hoffmann H (2011) Management of chylothorax in adults: when is surgery indicated? Thorac Cardiovasc Surg 59: 243.

12. Maldonado F, Hawkins FJ, Daniels CE, Doerr CH, Decker PA, et al. (2009) Pleural fluid characteristics of chylothorax. Mayo Clin Proc 84: 129-133.

13. Park JG, Aubry MC, Godfrey JA, Midthun DE (2006) Mediastinal lymphangioma: Mayo Clinic experience of 25 cases. Mayo Clin Proc 81: 1197.

14. Bessone LN, Ferguson TB, Burford TH (1971) Chylothorax. Thorac Surg 12: 527-550

15. Akcali O, Kiray A, Ergur I, Tetik S, Alici E (2006) Thoracic duct variations may complicate the anterior spine procedures. Eur Spine J 15(9): 1347-1351.

16. Bhat AL, lowery GL (1997) Chylous injury following anterior spinal surgery: Case reports. Eur Spine J 6: 270-272.

17. Adeeb Derakhshan, Daniel Lubelski, Michael P. Steinmetz, Mark Corriveau, Sungho Lee, et al. (2017) Thoracic Duct Injury Following Cervical Spine Surgery: A Multicenter Retrospective Review. Global Spine Journal 7: 115S-119S.

18. Townshend AP, Speake W, Brooks A (2007) Chylothorax. Emerg Med J 24: 11.

19. Akin H, Olcmen A, Isgorucu O, Denizkiran I, Dincer I (2012) Approach to patients with chylothorax complicating pulmonary resection. Thorac Cardiovasc Surg 60: 135-139. 